\title{
Implementation of Social Forestry Policy Around The Meranti Sungai Merah Protection Forest Area
}

\author{
$\operatorname{Heripan}^{1 *}$, Ridhah Taqwa ${ }^{1}$, Dwi Putro Priadi ${ }^{1}$, Noril Milantara ${ }^{2}$, Jun Harbi ${ }^{2,3}$ \\ ${ }^{1}$ Graduate Program Student, Environmental Management, Sriwijaya University, Palembang, Indonesia \\ ${ }^{2}$ Forestry Department, Muhammadiyah University of Palembang, Palembang, Indonesia \\ ${ }^{3}$ Forestry Economics and Management, Northeast Forestry University, Harbin, China \\ *Corresponding author, e-mail: heripanh@gmail.com
}

\begin{tabular}{|c|c|c|c|}
\hline & & & \\
\hline 30 March 2019 & 27 April 2019 & 09 May 2019 & 14 May 2019 \\
\hline
\end{tabular}

\begin{abstract}
One of the concrete efforts made by the Indonesian government is through social forestry policy as a trigger for land conflicts. One area that has implemented a pattern of social forestry is a forest area located in the management area of KPH Region I Meranti,Musi Banyuasin Regency. The aims of this study was to find out and analyze the process of implementing social forestry policy and analyze the factors that influence. The study was conducted in Pangkalan Bulian and Lubuk Bintialo Villages, Batang Hari Leko District, Musi Banyuasin Regency, South Sumatra Province. This Research used quantitative and qualitative research approach. Funding and staff resources (human resources) are still lacking. The process of collective action between actors is running well. Technical rules are clear with the existence of SOPs that are derived from the rules of government and local government. Communication goes well between communities (Forest farmer groups and cooperative members) - local government and facilitators, but not so well between government structures (village heads and apparatus and local government). Generally, the social forestry policy in this area has been effectively implemented from the perspective of policy accuracy in resolving forestry problems and environmental accuracy in accepting policies.

Keywords: social forestry, protected forest, lubuk bintialo, pangkalan bulian
\end{abstract}

\begin{abstract}
Abstrak (Indonesian): Salah satu upaya nyata yang dilakukan oleh pemerintah Indonesia adalah melalui kebijakan kehutanan sosial sebagai solusi untuk konflik tanah. Salah satu daerah yang telah menerapkan pola perhutanan sosial adalah kawasan hutan yang berada di wilayah kelola KPH Wilayah I Meranti, Kabupaten Musi Banyuasin. Tujuan penelitian ini adalah untuk mengetahui dan menganalisis proses penerapan kebijakan kehutanan sosial dan menganalisis faktor-faktor yang mempengaruhi. Penelitian dilakukan di Desa Pangkalan Bulian dan Desa Lubuk Bintialo, Kecamatan Batang Hari Leko, Kabupaten Musi Banyuasin, Provinsi Sumatera Selatan. Penelitian ini menggunakan pendekatan kuantitatif atau kualitatif. Berdasarkan data yang dianalisis, sumber dana dan staf (sumber daya manusia) masih kurang. Proses aksi kolektif antar aktor berjalan dengan baik. Aturan teknis jelas dengan adanya SOP yang berasal dari aturan pemerintah dan pemerintah daerah. Komunikasi berjalan dengan baik antara masyarakat (kelompok tani hutan dan anggota koperasi) - pemerintah daerah dan fasilitator, tetapi tidak begitu baik antara struktur pemerintah (kepala desa dan aparat dan pemerintah daerah). Secara umum, kebijakan perhutanan sosial di wilayah ini telah secara efektif dilaksanakan dari perspektif akurasi kebijakan dalam menyelesaikan masalah kehutanan dan akurasi lingkungan dalam menerima kebijakan.

Kata kunci: perhutanan sosial, hutan lindung, lubuk bintialo, pangkalan bulian
\end{abstract}

\section{Introduction}

Forests provide critical ecosystem services, including regulating the earth's climate and watersheds, and contributing to livelihoods worldwide [1]. Indonesia is a big nation with 120.6 million hectares or $63 \%$ of the nation's entire land area designated as the Forest Area (MEF, 2018). Indonesia contributes significantly to deforestation in Southeast Asia. Deforestation trend in Indonesia started in 1970 [3]. During 2000-2010, forest loss out to 14.7 million hectares [4]. Deforestation that occurs in 2017 was $480.010,8 \mathrm{Ha}$, decreased from the previous year which was 629,177 Ha (MEF, 2018b, 2017) Deforestation is causing growing population and transmigration policy and associated with theexpansion of agricultural land [1], [3], [7], [8] especially for cultivated land or oil palm plantation by farmers and companies [9], [10]. This is a trigger for land conflicts[11]so that a solution is needed in the form of forest management with the community [12] to balance development and conservation[13]in the form of reducing community poverty, empowering it and improving forest conditions [14]-[17]. One of the concrete efforts made by the government is through social forestry policy [18] which has been a global trend for the past 2 decades [19].

This policy is an implementation of the mandate of Law No. 41 of 1999 concerning Forestry, which is stated in article 3 letter $\mathrm{d}$ that the implementation of forestry aims to maximize the prosperity of the people that is just and sustainable by increasing the capacity to develop capacity and empower participatory, fair and environmentally sound so as to create social and economic resilience as well as external change. In 
addition to this article the participation and rights of the community in forestry development are also regulated in articles 23, 67, 68, 69 and 70 [20].

According to Minister of Environment Forestry Regulation No. P.83 of 2016 concerning social forestry, social forestry is an effort to reduce poverty, unemployment and inequality in the management of forest areas [21]. This social forestry program policy was made to complement existing community-based forest management schemes [22] such as Community Plantation Forests (HTR), Community Forestry (HKm), Community Forestry (HR), Village Forests (HD) and collaboration forms of forest management between private companies and entrepreneurs [23]. In the social forestry scheme, the government opens up greater access to communities located around the forest to utilize forest areas in the form of timber and non-timber forest products through nursery, planting, maintenance, harvesting, processing, and marketing based on forest conservation principles. In accordance with the 20152019 National Medium-Term Development Plan (RPJMN) [24], the Ministry of Environment and Forestry is tasked with allocating an area of 12.7 million hectares of forest for social forestry activities involving the community.

One area that has implemented a pattern of social forestry is a forest area located in the management area of the Regional Technical Implementation Unit(UPTD) KPHRegion I Meranti located in Musi Banyuasin Regency. As of 2018, there have been 4 social forestry permits issued [25]. The existence of social forestry permits in this area aims to reduce critical land and tenurial conflicts[26] between the government / private companies and the community, especially in the management area of the Meranti Sungai Merah Protection Forest (HL MSM) which is stated in very critical conditions. This location is adjacent to the Dangku Landscape which is a conservation area and is one of the tiger cruising routes [27]involving many interested actors[28]. It is hoped that there will be a middle ground solution to bridge economic and ecological needs in this region [29]. At present there are 8,932 ha or $78.5 \%$ of HL MSM land which are in the critical category[30] and are estimated to overlap $38.53 \%$ of the total area between the community, the private sector and the government [31].

There are two villages around the HL MSM area, namely Lubuk Bintialo Village and Pangkalan Bulian Village [29], [30]. In these forest areas there are 39 forest farmer groups $(\mathrm{KTH})$ that manage land in the two villages [32]with 3 community categories including: 1) local communities, 2) local transmigrants, for example: former employees and workers of the HPH era, and 3) official transmigrants (government programs) and nonprogram government entrants from other provinces [26]. Contrary to the condition of the high level of occupation of forest areas, only 3 social forestry scheme permits have been issued. Because policies have an important role in forest management [33], based on this background, a study needs to be conducted to find out and analyze the process of implementing social forestry policies in Musi Banyuasin District especially Lubuk Bintialo Village and Pangkalan Bulian Village as an effort to preserve HL MSM regularly help improve people's welfare. So the purpose of this study was to find out and analyze the process of implementing social forestry policy in Musi Banyuasin Regency and analyze the factors that influence the implementation of the policy in the form of reality of communication, adequacy of resources, accuracy of disposition; and bureaucratic structures in the form of SOPs (Standard Operational Procedures).

\section{Material and Methods}

The study was conducted in the Meranti Sungai Merah Protected Forest area (HL MSM) located in the management area of the RegionalTechnical Implementation Unit Forest Management Unit (UPTD $\mathrm{KPH})$ Region 1 Meranti. Administratively, this area intersects with the area of Pangkalan Bulian and Lubuk Bintialo Villages, Batang Hari Leko District, Musi Banyuasin Regency, South Sumatra Province (Figure 1). The selection of research locations (2 location villages) was chosen purposively (intentionally) because it was a village directly adjacent to the Meranti Sungai Merah Protected Forest area (HL MSM).

The type of research used is descriptive method combined (mixed methods) from two different approaches namely quantitative or qualitative approaches. There are 2 types of data used, namely primary and secondary data. Primary data is obtained through observation of the management area of social forestry and interviews conducted in semi-structured (indepth interviews) with relevant parties (informants). Determination of informants is done by pusposing and followed by snowball. Purposive determination was made of individuals who were actively and non-actively involved in the implementation of social forestry policies (Table 1).

The number of informants interviewed in this study amounted to 40 peoples. The dissemination of information from one information to another takes place by means of snowball, which starts from an informant who may have little knowledge of the problems under study and turn to informants who have greater involvement or have more knowledge related to the implementation of social forestry policies. Secondary data is obtained through collecting documents as supporting social forestry data. The secondary data referred to in accordance with Table 2.

After obtaining the data, then it is to analyze the data to answer written research questions. Data analysis according to Patton is the process of arranging data sequences, organizing them into a basic description category and unit pattern. Furthermore, data analysis is carried out quantitatively to see the status of social 
forestry areas. Spatial analysis was carried out with the ArcGIS 10.5 tool to get the distribution of PIAPS around the MSM protected forest. In addition, a qualitative analysis was also conducted to see the factors of policy implementation.

Table 1. List of Key Infomants

\begin{tabular}{|c|c|}
\hline No & Position and institution \\
\hline 1 & Head of Forest Office of South Sumatra Province \\
\hline 2 & Head ofForest Area Consolidation Center (BPKH) regional 5 Palembang \\
\hline 3 & Head of Bidang Penyuluhan dan Pemberdayaan Masyarakat, Dinas Kehutanan Sumsel \\
\hline 4 & Head of UPTD KPH Wil. I Meranti \\
\hline 5 & Penyuluh kehutanan UPTD KPH Wil. 1 Meranti \\
\hline 6 & Head ofWorking Group on the Acceleration of Social Forestry (Pokja PPS) \\
\hline 7 & Head of Lubuk Bintialo Village \\
\hline 8 & Head of Pangkalan Bulian Village \\
\hline 9 & Head ofVillage Cooperation Unit (KUD) Tunggal Karya Sehati, Lubuk Bintialo Village \\
\hline 10 & Member of KUD Tunggal Karya Sehati Lubuk Bintialo Village ( 3 peoples) \\
\hline 11 & Head of Gapoktan Meranti Wana Makmur Lubuk Bintialo Village \\
\hline 12 & Member ofGapoktan Meranti Wana Makmur Lubuk Bintialo Village (3 peoples) \\
\hline 13 & Head of Gapoktan Makmur Bersama Lubuk Bintialo Village \\
\hline 14 & Member of Gapoktan Makmur Bersama Lubuk Bintialo Village (3 peoples) \\
\hline 15 & Head of Gapoktan Karya Indah Lubuk Bintialo Village \\
\hline 16 & Member of Gapoktan Karya IndahLubuk Bintialo Village (3 peoples) \\
\hline 17 & Head of Gapoktan Bulian Sejahtera Pangkalan Bulian Village \\
\hline 18 & Member ofGapoktan Bulian Sejahtera Pangkalan Bulian Village (3 peoples) \\
\hline 19 & Head ofKetua Gapoktan Sungai Merah Lestari Pangkalan Bulian Village \\
\hline 20 & Member of Gapoktan Sungai Merah Lestari Pangkalan Bulian Village (3 peoples) \\
\hline 21 & Head of Gapoktan Mitra Bersama Sejahtera Pangkalan Bulian Village \\
\hline 22 & Member ofGapoktan Mitra Bersama Sejahtera Pangkalan Bulian Village (3 peoples) \\
\hline 23 & Head of Program Studi Kehutanan UMPalembang (Academician) \\
\hline 24 & Hutan Kita Institute-HaKI (NGO) \\
\hline 25 & Lingkar Hijau (NGO) \\
\hline 26 & Kelola Sendang Project, Zoological Society of London-ZSL (South Sumatra green development member) \\
\hline
\end{tabular}

Table 2. Secondary Data and Sources

\begin{tabular}{cll}
\hline No & \multicolumn{1}{c}{ Data } & \multicolumn{1}{c}{ Sources } \\
\hline 1 & Decree and licensing documents (work plan, member & Gapoktan/KUD/LPHD/ UPTD KPH Wil. 1 Meranti/forest \\
& name, area map, etc.) of social forestry. & office/ NGO and green development member as facilitators \\
2 & Socio-economic data, village potential, and population. & Statistic Bereau \\
3 & Map of forest areas, Indicative Maps and Social & BPKH Reg. 5 Palembang, ICRAF \\
& $\begin{array}{l}\text { Forestry Areas (PIAPS) of South Sumatra and MSM } \\
\text { HL satellite imagery }\end{array}$ & \\
\hline
\end{tabular}

Referring to Irawan (2006) and Miles and Huberman (1992), the data analysis is done by: 1) Data reduction, after from the research location, the field data obtained is poured, reduced and summarized, and then sorted things out important and look for patterns or themes through the process of editing and coding; 2) Data display, has the purpose to make it easier for researchers to see the overall picture or certain parts of the research data so that it allows the conclusion and action taking; and 3) Conclusing drawing/verification.

These three stages are interrelated at the time before, during and after data collection in a form that is parallel and is a cycle and interactive process. This study uses the Edward III model policy implementation approach, namely the implementation of policies that are influenced by 4 variables such as resources, communication, disposition and bureaucratic structure (Table 3).

Table 3. Variable and dimensions of research focus (Edwards III Model, 1984)

\begin{tabular}{cll}
\hline No & \multicolumn{1}{c}{ Variable } & \multicolumn{1}{c}{ Dimension } \\
\hline 1 & Resources & Human, Information, Authority and Budget (facilities) \\
2 & Communication & Information transmission, clarity and ability to convey information (consistency) \\
3 & Disposition & Attitudes and incentives of social forestry actors.. \\
4 & Bureaucratic structure & Standar Operating Procedures (SOP) and fragmatation \\
\hline
\end{tabular}




\section{Results and Discussion}

\subsection{Existing Conditions of Social Forestry at the} Research Site

Based on Law 41 of Forestry and PP No. 6/2007 concerning Forest Arrangement and Preparation of Forest Management Plans, and Forest Utilization, activities that can be carried out in protected forest areas include utilization of the area (in the form of medicinal plants, ornamental plant cultivation, mushroom cultivation, bee cultivation, wildlife breeding, animal rehabilitation and forage farming), utilization of environmental services (in the form of utilization of water flow services, utilization of water, natural tourism, biodiversity protection, rescue and environmental protection and absorption and / or carbon storage) and collection of non-timber forest products (in the form of rattan, honey, sap, fruit, mushrooms and swallow's nest).
But in its implementation, these activities in principle have provisions that do not reduce, change or eliminate its main function, limited land cultivation, do not cause negative impacts on biophysics and socio-economics, do not use mechanical equipment and heavy equipment, do not build facilities and infrastructure that change landscapes and must obtain forest utilization permits in protected forests[34].

The governance of the use of protected forest areas is contrary to the reality of the MSM protection forest. Based on the results of satellite imagery (Table 4), land cover at HL MSM leaves only 39\% of secondary forest in the form of rubber plantations. The rest has changed function with activities outside forestry (arable land) without permission. In fact, $4 \%$ of the area has become a community settlement. This is clearly deviated from the rules set by the government.

Table 4. Forest Cover of MSM Protected Forest year 2000-2014

\begin{tabular}{|c|c|c|c|c|c|c|c|c|c|c|c|c|c|}
\hline \multirow{2}{*}{ No } & \multirow{2}{*}{ Forest Cover } & \multicolumn{2}{|c|}{2000} & \multicolumn{2}{|c|}{2003} & \multicolumn{2}{|c|}{2006} & \multicolumn{2}{|c|}{2009} & \multicolumn{2}{|c|}{2011} & \multicolumn{2}{|c|}{2014} \\
\hline & & Ha & $\%$ & $\mathrm{Ha}$ & $\%$ & $\mathrm{Ha}$ & $\%$ & $\mathrm{Ha}$ & $\%$ & & & На & $\%$ \\
\hline 1 & Secon & 4524.8 & 40 & 4524.8 & 40 & 4527.8 & 40 & 4527.8 & 40 & 4527.841 & 40 & 4446.1 & 39 \\
\hline 2 & Mixed & 3400.1 & 30 & 3400.1 & 30 & 3399.0 & 30 & 3399.0 & 30 & 3399.031 & 30 & 3370.0 & 30 \\
\hline 3 & Shrub & 1993.4 & 17 & 1993.4 & 17 & 1991.3 & 17 & 1991.3 & 17 & 1991.31 & 17 & 2092.9 & 18 \\
\hline 4 & Planti & 1054.4 & 9 & 1054.4 & 9 & 1053.7 & 9 & 1053.7 & 9 & 1053.7 & 9 & 1047.5 & 9 \\
\hline 5 & Comn & 461.3 & 4 & 461.3 & 4 & 462.2 & 4 & 462.2 & 4 & 462.2 & 4 & 466.6 & 4 \\
\hline 6 & Opened area & 0.0 & 0 & 0.0 & 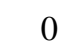 & 0.0 & 0 & 0.0 & 0 & 0.0 & 0 & 10.8 & 0 \\
\hline & Total & 34.1 & 10 & 4.1 & 10 & 4341 & & 34.1 & & 4.110 & & 434 & \\
\hline
\end{tabular}

At present, MSM protected forest vegetation is dominated by several types including grasslands, open land, shrubs and forests with high and low density [35]. High and low-density forests are dominated by old rubber plantations which are not well managed and harvested for generations [29] and experience fragmentation [27]. Referring to Perdirjen P.4/2013 (regarding the criticality of land and priority rehabilitation categories), in the MSM protected forest area there are $2,442 \mathrm{Ha}$ or $21.5 \%$ of the MSM protected forest area is in critical status to be very critical and a priority for rehabilitation. As much as $57.0 \%$ or 6,490 ha of protected forest area are in a rather critical status. Distribution of the distribution of critical status to very critical areas has a pattern that spreads around the area that can be accessed by road or river. It means that the area becomes the area that is passed or is the land where the community conducts its activities. Thus socioeconomic factors also trigger the criticality of the MSM protected forest area [30].

The process of changing land cover that indicates a change in the function of this land has long begun. Based on the image of satellite imagery in figure 2 shows that land management for various non-forestry activities has begun before 2000. Furthermore, forest functions have not been readjusted according to their functions and even deforestation occurred in 2014 with a reduction in secondary forests and increased shrubs. In addition, this also indicates that the process of management of this protected forest by the community has been carried out for at least more than 18 years, so that in accordance with the Republic of Indonesia Presidential Regulation Number 88 of 2017 concerning Land Settlement in Forest Areas, it is only natural that this area gets forest management permits through a social forestry program if the arable land has been controlled for less than 20 (twenty) years and issues land parcels from within the forest area through changes in forest area boundaries if it has been controlled for more than 20 (twenty years) [36].

Following up on the existing conditions, as a solution to the midpoint, the government issued permits for access to management in the form of social forestry for protected forests because the participation of the community in the form of social capital (customs, norms, beliefs, leadership and social institutions) that exist in communities around the forest. That seen from the perspective of the actor and the public point of view relate to increasing forest sustainability [37]. So that, adjusting to the conditions that have occurred on the site, the licensing of social forestry management in this region is expected to be more widespread. 


\subsection{Dynamics of Social Forestry Governance in Musi Banyuasin District}

The process of issuing social forestry permits at the research site has only been carried out since the existence of a social forestry policy in 2016 and proposals began in 2018. However, in general, the process of proposing social forestry in Musi Banyuasin District began in 2009 with the proposed village forest in Muara Merang and in 2010 at the Muara Medak and Kepayang (area of UPTD KPH Region 2 Lalan). Village Forest Management Rights (HPHD) permits began to be issued in 2010 for Muara Merang Village (Muara Merang LPHD) and in 2015 for Kepayang Village (LPHD Kepayang) even though to date village forest management has not been carried out optimally.

This is in line with the conditions of social forestry in general in Indonesia. The realization of social forestry is considered slow and does not have a significant impact on various aspects of community livelihoods and forest sustainability. The occurrence of these conditions is due to regional unpreparedness in the implementation of social forestry after the issuance of Law 23/2014 concerning Regional Government [38]. After 2015, the social forestry permit process was not followed up until 2018.

Implementation requires the implementor to know what must be done, communication is defined as the process of delivering information between the communicators [39]. Edward III (1980) states that resource factors have an important role in policy implementation. Although the contents of the policy have been clearly and consistently communicated, if policy implementers are responsible for implementing a policy of lack of resources to do work effectively, then the implementation of the policy will not be effective. The intended resources are human resources, facilities, authority and support (rules of the game) available to help carry out social forestry implementation activities.

Table 5. Data of Social Forestry in area of UPTD KPH Reg. 1 Meranti

\begin{tabular}{|c|c|c|c|c|c|c|}
\hline No & Name & Village & Size (Ha) & Scheme & Facilitator & Status \\
\hline 1 & Gapoktan Lestari Bulian Sejahtera & Pangkalan Bulian & $1.596,90$ & KK- KPH & Lingkar Hijau & 2 \\
\hline 2 & KUD Tunggal Karya Sehati & Lubuk Bintialo & 4.915 & HTR & KPH Meranti & 1 \\
\hline 3 & Gapoktan Meranti Wana Makmur & Lubuk Bintialo & 513,27 & $\mathrm{HKm}$ & ZSL & 1 \\
\hline 4 & Gapoktan Meranti Makmur Bersama & Lubuk Bintialo & 410.92 & KK- KPH & KPH Meranti & 2 \\
\hline 5 & Gapoktan Bukit Sumber Mas & Pagar Desa & 489,08 & KK- KPH & KPH Meranti & 1 \\
\hline 6 & KTH Bukit Sentosa Mas & Pagar Desa & 79,28 & KK-PT. RHM & KPH Meranti & 2 \\
\hline \multirow[t]{2}{*}{7} & Gapoktan Maju Bersama & Simpang Bayat & 710 & $\mathrm{HKm}$ & Lingkar Hijau & 1 \\
\hline & \multicolumn{2}{|l|}{ Sub Total } & \multicolumn{2}{|l|}{$8.714,45$} & & \\
\hline 8 & Gapoktan Karya Indah & Lubuk Bintialo & 360.00 & HTR & KPH Meranti & 3 \\
\hline 9 & KTH Tani Jaya & Lubuk Bintialo & 60 & $\mathrm{HKm}$ & KPH Meranti & 3 \\
\hline 10 & $\begin{array}{l}\text { Gapoktan Mitra } \\
\text { BersamaSejahtera }\end{array}$ & Pangkalan Bulian & 890.64 & HTR & KPH Meranti & 3 \\
\hline 11 & Gapoktan Sungai Merah Lestari & Pangkalan Bulian & 770.94 & HTR & KPH Meranti & 3 \\
\hline 12 & KTH Keban Hijau Lestari & Keban & 328.63 & HTR & KPHMeranti & 3 \\
\hline 13 & Gapoktan Tunas Muda & Pagar Desa & 1.936 & $\mathrm{HKm}$ & Lingkar Hijau & 3 \\
\hline \multirow{2}{*}{\multicolumn{3}{|c|}{ Sub Total }} & 4.346 .21 & & & \\
\hline & & & 13.060 .66 & & & \\
\hline
\end{tabular}

Source: UPTD KPH Regional 1 Meranti

Note: $1=$ got permission $2=$ verified $3=$ submission

Human resources are one of the variables that influence the success of policy implementation. Human resources must be sufficient (number), and competent (expertise) [40]. Although communication is good and consistent and has been properly transformed, but if human resources are limited both in quantity and quality, the implementation of policies will not be effective [39]. But on the contrary if human resources are sufficient in number and quality, but the information obtained in relation to the implementation of policies from superiors above is insufficient, the implementation of policies will also not be effective. Therefore, human resources must have accuracy and feasibility between the number of staff needed and expertise possessed in accordance with the work tasks they handle.

Implemention of social forestry policies at the
UPTD KPH Reg.1 Meranti is still constrained by the lack of staff involved to succeed in implementing social forestry policies. Staff involved in the form of forestry extension officers are only 1 (one) person. Even though forestry counseling is very influential on increasing community knowledge about forests [41]. This condition is considered not ideal when considering the amount of forest farmer group and the work area (Table 6). Not only in Muba Regency, this condition is experienced evenly in all districts / cities in South Sumatra. The distribution of forestry extension workers is not balanced between districts without considering the amount of forest farmer group and the area of management. This must be the concern of policy implementers because forestry extension agents are the key to connecting communication between policy and the community. 


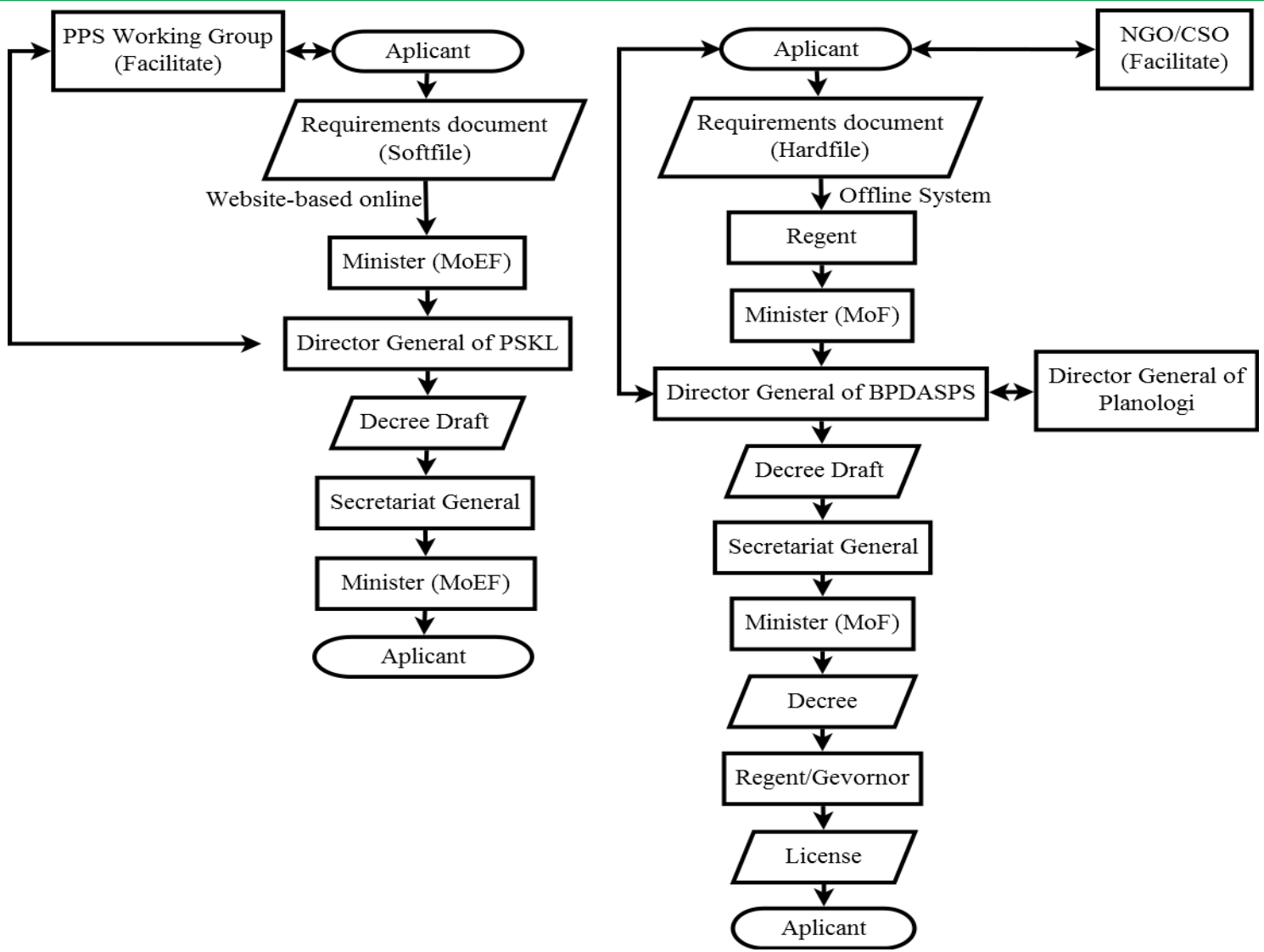

Figure 3. The process of issuing social forestry permits: old (right) and new (left)

Notes: old $=$ according to Permenhut P.89/Menhut-II/2014

new $=$ according to PermenLHK P.83/3016

Table 6. Number of forestry extensions and forest farmer groups (KTH) as well as forest area and KPH management area in South Sumatra 2017

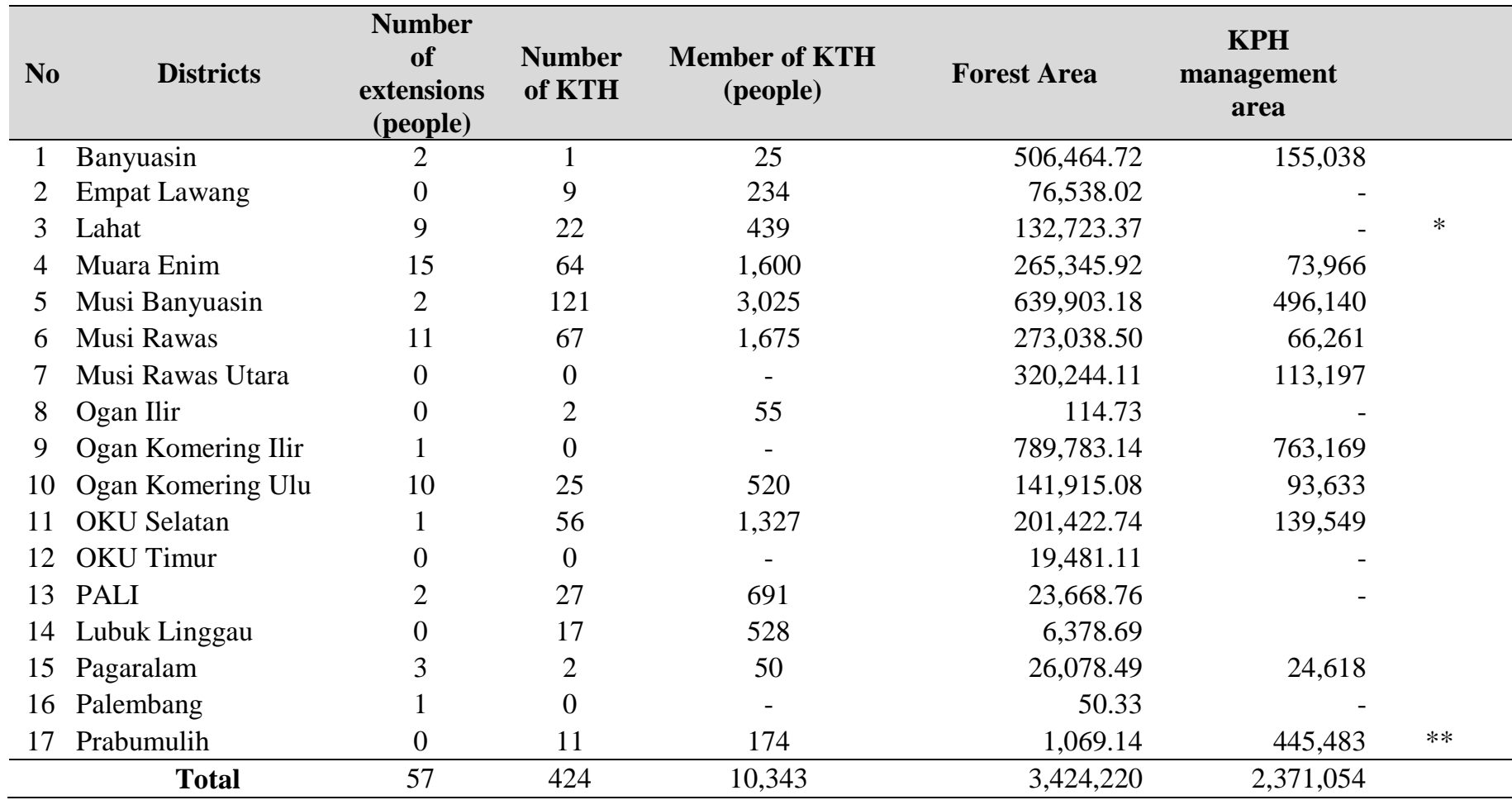

Source: South Sumatra Forest Office

One of the supporting factors for social forestry management in this region is the active contribution of external actors gathered in the members of the Working
Group on the Acceleration of Social Forestry (Pokja PPS). The formation of the PPS Working Group which refers to Perdirjen PSKL No. 
P14./PSKL/Set/PSL.0/11/2016 Regarding Guidelines for Facilitation, Formation and Procedures for Working Group on the Acceleration of Social Forestry (Pokja PPS) and described in the Governor of South Sumatra Regulation No. 58 of 2018 concerning the Implementation of Social Forestry, a PPS Working Group was formed in South Sumatra based on the Decree of the Governor of South Sumatra No. 154 / KPTS / Dishut / 2017 concerning the Establishment of the Working Group for the Acceleration of Social Forestry of South Sumatra Province in 2017-2020.

One of the supporting factors for social forestry management in this region is the active contribution of external actors gathered in the members of the Working Group on the Acceleration of Social Forestry (Pokja PPS). The formation of the PPS Working Group which refers to Perdirjen PSKL No. P14./PSKL/Set/PSL.0/11/2016 Regarding Guidelines for Facilitation, Formation and Procedures for Working Group on the Acceleration of Social Forestry (Pokja PPS) and described in the Governor of South Sumatra Regulation No. 58 of 2018 concerning the Implementation of Social Forestry, a PPS Working Group was formed in South Sumatra based on the Decree of the Governor of South Sumatra No. 154 / KPTS / Dishut / 2017 concerning the Establishment of the Working Group for the Acceleration of Social Forestry of South Sumatra Province in 2017-2020.

The implementation of social forestry policies is not necessarily detached from the clear rules that overshadow this policy as supporting resources. This technical rule will provide clarity of authority, responsibilities and main tasks as well as the functions of the institutions involved. Clarity of the rules of the game is one of the differences with social forestry rules before
2016 which is considered as one of the causes of failure [42]. As a follow up to the social forestry policy, several derivative regulations were issued both at the national level, South Sumatra and the rules of the PPS Working Group. This technical rule is important as a resource so that it becomes a reference in implementing social forestry. The technical rules as shown in Table 7.

Edward III (1980) asserted that the success of policy implementation is not only determined by the extent to which policy makers (implementors) know what to do and are able to do it, but also determined by the willingness of policy actors to have a strong disposition towards policies being implemented. Knowledge, deepening, and understanding of policy, this will lead to acceptance, neutrality, and rejection of policy. That attitude will lead to the disposition of the policy actors themselves. High dispositions affect the level of success of policy implementation. This disposition is a willingness, desire, and tendency of policy actors to implement policies seriously, so that what becomes the policy objectives can be realized. Therefore, disposition is defined as the character / characteristics possessed by the executor of the policy, the disposition is like commitment, honesty, and democratic nature [39].

The manifestation of the implementation of social forestry policies in the UPTD KPH Reg. 1 Meranti area, so Hutan Kita Institute (HaKI) and Lingkar Hijau as part of NGOs and Kelola Sendang Project (ZSL) as part of green development partners also contribute to accelerating forestry implementation social at the site level, both contributions in counseling, socialization, proposals, facilitation of work plan preparation, and funding to encourage economic activities in the social forestry area.

Table 7. List of Rules for Management of Social Forestry at South Sumatra

\begin{tabular}{cll}
\hline No & \multicolumn{1}{c}{ Rules } & \multicolumn{1}{c}{ Content } \\
\hline 1 & Perdirjen PSKL P.1/2016 & Tata Cara Verifikasi dan Validasi Hutan Hak \\
2 & Perdirjen PSKL P.3/2016 & Pedoman Pengembangan Usaha Perhutanan Sosial \\
3 & Perdirjen PSKL P.4/2016 & Pedoman Mediasi Penangaan Konflik Kaw. Hutan \\
4 & Perdirjen PSKL P.6/2016 & Pedoman Asesmen Konflik Tenurial Kawasan Hutan \\
5 & Perdirjen PSKL P.7/2016 & Pelayanan Akses Kelola Perhutanan Sosial \\
6 & Perdirjen PSKL P.9/2016 & Perubahan Perdirjen PSKL P.3/2016 \\
7 & PerdirjenPSKL P.11/2016 & Pedoman Verifikasi Permohonan HPHD \\
8 & Perdirjen PSKLP.12/2016 & Pedoman Verifikasi Permohonan IUPHKm \\
9 & Perdirjen PSKLP.13/2016 & Pedoman Verifikasi Permohonan IUPHHK-HTR \\
10 & PerdirjenPSKLP.14/2106 & Pedoman Fasilitasi, Pembentukan dan Tata Cara Kerja Pokja PPS \\
11 & PerdirjenPSKLP.18/2016 & Pedoman Penyusunan Naskah Kesepakatan Kerjasama \\
12 & Pergub Sumsel 58/2018 & Penyelenggaraan Perhutanan Sosial \\
13 & SK Gub. Sumsel 154/2017 & Pembentukan Pokja PPS Sumsel Tahun 2017-2020 \\
14 & SK Forum DAS Sumsel 008/2012 & Pembentukan Pokja PPS Sumsel P 2012-2017 \\
15 & SK Gub. Sumsel 717/2017 & Perubahan atas SK Gub.Sumsel 154/KPTS/DISHUT/2017 \\
\hline
\end{tabular}

Policy actors consisting of governments and local governments have a high commitment to the implementation of social forestry policies. This can be seen from the existence of this common policy in various programs and aspects such as fund allocation, publication and distribution of human resources. This commitment was realized with the establishment of implementing elements in the LHK ministry who had the task of formulating and implementing technical policies and standardization in the field of social forestry in the 
form of the Directorate of Social Forestry and Environmental Partnerships (DG PSKL). Contradictory conditions occur at the village government level where attention to the implementation of social forestry programs is considered lacking. This can be seen from the absence of contributions from the village government program (the results of the village development forum) on the management of forest farmer groups in implementing social forestry.

This condition indicates the difficulty of elaboration between the village government and forestry farmer groups has a considerable impact on the escort and internalization of social forestry schemes by the community and village institutions. This signals that the existence of social forestry is not an integral part of village development, alleviation of the poor, while building the socio-economic independence of the poor in and around the forest [43].

SOPs can be interpreted as a set of work orders or steps that must be followed to carry out a work based on the objectives to be achieved [44]. SOP as a source, purpose and technical guide for policy implementation, local government (Forestry Service of South Sumatra Province) as a regional level implementing party through PPM (Community Development and Development) with authority distributed to the UPTD Wil KPH. I as an implementer at the site level has clear and measurable standards to become the basis for implementing social forestry policies. This can be seen from the implementation of the policy in accordance with the applicable rules and the clear technical rules that exist in Table 7. According to all parties involved, especially the government as policy implementers and external actors (NGOs and green sumsel development partners), academics, etc. the technical regulations that have been issued have sufficiently accommodated the technical rules of social forestry.

\subsection{Effectiveness of Social Forestry Policy: Synthesis of Research Results}

At least there are 3 keys to success in implementing community-based forest management including: 1) Policy environment factors, in the form of the role of NGOs, characteristics and support of target groups and dispositions of regional heads. The implementation process begins with good socialization by accompanying NGOs so that community enthusiasm emerges in guarding the participatory implementation process, 2) Factors in the availability of resources which include human resources and financial resources; and 3) Factor accuracy of policy instruments [42]. In the implementation of social forestry policies found several main problems that are the cause of the slow granting of licenses, namely the problem of bureaucracy, institutions and funding, and knowledge.

The proposed location of social forestry in the range of 2014-2015 was affected by the transfer of authority from region to province. So that there are transitions and adjustments to data collection and other resources. The function of escorting proposals at the site level is slow because the changes in authority make repositioning of structures in regional forestry institutions. So that the technical role does not run optimally during the transition period. In addition to changes in technical personnel, changes in the authority of the social forestry policy initially handled by the Watershed Utilization Center (BPDAS) were transferred to the Social Forestry and Environmental Partnership (PSKL). So that the transformation was also allegedly contributing to the delay in the process of proposing and granting forest utilization business licenses.

In general, the implementation of social forestry policies in the work area of the UPTD KPH Reg. 1 Meranti is quite good/effective. But, there are several important notes including:

1. Funding and staff resources (human resources) are still lacking.

2. The process of collective action between actors is running well with the existence of a committed PPS Working Group.

3. Technical rules are clear with the existence of SOPs that are derived from the rules of government and local government.

4. Communication goes well between communities (Forest farmer groups and cooperative members) local government and facilitators, but not so well between government structures (village heads and apparatus and local government).

\section{Indicator: legal access area}

Function: Regulators

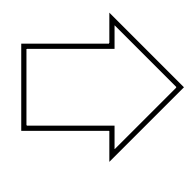

\section{Indicator: state revenue}

Function: Facilitator

Figure 4. Recommendations for changing the mindset of social forestry management

In the future, a change of mindset is needed in the management of social forestry (figure 4). The indicator of success is no longer the area of granting legal access to forest farmer groups, but rather the contribution of state revenue from forest utilization through social forestry efforts [43]. So that the government's focus in the future is not only the functions of regulators and benefit providers and services that make rules and complaints as well as administrative records, but as facilitators/enablers and are expected to be accelerators of sustainable, equitable and community-based forest management that enables initiatives and community independence. 


\section{Conclusion}

The conclusions from this study include:

1. The Social forestry policy in Musi Banyuasin District, South Sumatra has been effectively implemented from the perspective of policy accuracy in resolving forestry problems and environmental accuracy in accepting policies.

2. Factors in the implementation of social forestry policies include: the process of communication between implementing policies has been going well. The resources used(site level staff and budget) in implementing the policy can be said to be insufficient in terms of quantity and quality. Authority in implementing this policy is the responsibility of the Directorate of Social Forestry and Environmental Partnerships (PSKL) coordinated with the Forestry office of South Sumatra Province (Social Forestry Section) and carried out at the site level through the UPTD KPH Reg. 1 Meranti. In its implementation together with various parties who are members of the Working Group on the Acceleration of Social Forestry (Pokja PPS) of South Sumatra Province. Facilities used in policy implementation activities are not sufficient. Disposition in policy implementation has not been fully in accordance with the objectives or targets set. In the aspect of bureaucratic structure, social forestry implementation mechanism still seems top-down, Implementors prefer to fulfill SOPs rather than acting to meet the needs of the community. However, the SOP in this case the technical rules are sufficient to accommodate all policy implementation needs. Basically, the community supports the existence of a social forestry policy because it can accommodate the needs of the community for the legality of access to forest areas.

\section{References}

[1] C. Davis and R. Petersen, Tools for Monitoring Global Deforestation. Elsevier Inc., 2018.

[2] MEF [Ministry of Environment and Forestry Indonesia], The state of Indonesia's forests 2018. Jakarta, 2018.

[3] R. Tsujino, T. Yumoto, S. Kitamura, I. Djamaluddin, and D. Darnaedi, "History of forest loss and degradation in Indonesia," Land use policy, vol. 57, pp. 335-347, 2016.

[4] S. A. Abood, J. S. H. Lee, Z. Burivalova, J. GarciaUlloa, and L. P. Koh, "Relative Contributions of the Logging, Fiber, Oil Palm, and Mining Industries to Forest Loss in Indonesia," Conserv. Lett., vol. 8, no. 1, pp. 58-67, 2015.

[5] MEF [Ministry of Environment and Forestry Indonesia], Statistik Lingkungan Hidup dan Kehutanan Tahun 2016. Jakarta, 2017.

[6] MEF [Ministry of Environment and Forestry Indonesia], Statistik Lingkungan Hidup Dan Kehutanan Tahun 2017. Jakarta: Ministry of Environment and Forestry Indonesia, 2018.

[7] C. Yamamoto, C. Ishimura, C. Shigetomi, and C.
Chobe, "Forest change and agricultural productivity: Evidence from Indonesia," World Dev., vol. 114, pp. 196-207, 2019.

[8] C. Kubitza, V. V. Krishna, K. Urban, Z. Alamsyah, and M. Qaim, "Land Property Rights, Agricultural Intensification, and Deforestation in Indonesia," Ecol. Econ., vol. 147, no. February, pp. 312-321, 2018.

[9] A. Susanti and A. Maryudi, "Development narratives, notions of forest crisis, and boom of oil palm plantations in Indonesia," For. Policy Econ., vol. 73, pp. 130-139, 2016.

[10] H. Varkkey, A. Tyson, and S. A. B. Choiruzzad, "Palm oil intensification and expansion in Indonesia and Malaysia: Environmental and socio-political factors influencing policy," For. Policy Econ., vol. 92, no. May, pp. 148-159, 2018.

[11] E. N. Setiawan, A. Maryudi, R. H. Purwanto, and G. Lele, "Land Use Policy Opposing interests in the legalization of non-procedural forest conversion to oil palm in Central Kalimantan , Indonesia," Land use policy, vol. 58, pp. 472-481, 2016.

[12] H. Adnan, H. Berliani, G. Hardiyanto, Suwito, and D. K. Sakti, Pemberdayaan Masyarakat melalui Kemitraan Kehutanan. Panduan. 2015.

[13] L. Giessen and G. Buttoud, "Defining and assessing forest governance," For. Policy Econ. J., vol. 49, pp. 1-3, 2014.

[14] A. Maryudi et al., "Back to basics : Considerations in evaluating the outcomes of community forestry," For. Policy Econ., vol. 14, no. 1, pp. 1-5, 2012.

[15] T. Santika et al., "Community forest management in Indonesia: Avoided deforestation in the context of anthropogenic and climate complexities," Glob. Environ. Chang., vol. 46, no. December 2016, pp. 60-71, 2017.

[16] J. Baynes, J. Herbohn, C. Smith, R. Fisher, and D. Bray, "Key factors which influence the success of community forestry in developing countries," Glob. Environ. Chang., vol. 35, pp. 226-238, 2015.

[17] Agustini Syofia, A. H. Dharmawan, and E. I. K. Putri, "Bentuk Pengelolaan Hutan Nagari Sungai Buluh Kabupaten Padang Pariaman," Bhumi, vol. 3, no. November, pp. 267-278, 2017.

[18] I. Santoso, "Indonesian forestry policy and management," no. October, 2012.

[19] E. Furness, H. Harshaw, and H. Nelson, "Forest Policy and Economics Community forestry in British Columbia: Policy progression and public participation 方," For. Policy Econ., vol. 58, pp. 85-91, 2015.

[20] Republik Indonesia, Undang-Undang Republik Indonesia Nomor 41 Tahun 1999 Tentang Kehutanan. Indonesia, 1999.

[21] "Permen LHK Nomor P.83 tentang Perhutanan Sosial.pdf.".

[22] Rahmina, "Pilihan skema pengelolaan hutan berbasis masyarakat dalam mitigasi perubahan iklim," 2012. 
[23] E. Rosdiana, D. Bina, P. Sosial, and D. Kehutanan, "Skema-Skema Pemberdayaan," 2007.

[24] Republik Indonesia, Rencana Pembangunan Jangka Menengah Nasional 2015-2019. Indonesia, 2019.

[25] Dinas Kehutanan Provinsi Sumatera Selatan, "Laporan Monitoring Izin Perhutanan Sosial Di Wilayah Uptd Kph Provinsi Sumatera SelataN," Palembang, 2018.

[26] J. P. Napitu, A. Hidayat, S. Basuni, and S. Sjaf, "Conflicts of Utilization and Sustainable Production Forest Management $\mathrm{n}$ Forest in Management Unit of Meranti South Sumatera," J. Manaj. Hutan Trop., vol. 23, no. December, 2017.

[27] Zulfikhar, H. Zulkifli, S. Kadir, and I. Iskandar, "The Rapid Changes of the Landscape Structure of the Meranti-Dangku Tropical Lowland Forest in the South Sumatra Province, Indonesia," Sriwij. J. Environ., vol. 2, no. 1, pp. 8-18, 2017.

[28] D. Amalia, J. Sayer, C. Margules, and A. Klintuni, "Forest Policy and Economics Determining the effectiveness of forest landscape governance: A case study from the Sendang landscape , South Sumatra," For. Policy Econ., vol. 102, no. February 2018, pp. 17-28, 2019.

[29] J. Harbi, J. Thomas, M. Sidiq, and B. Haasler, "Forest Policy and Economics Making a bridge between livelihoods and forest conservation: Lessons from non timber forest products' utilization in South Sumatera, Indonesia," For. Policy Econ., vol. 94, no. May, pp. 1-10, 2018.

[30] S. Yunardy et al., "Pemetaan Lahan Terdegradasi dan Penentuan Prioritas Areal Rehabilitasi Skala Lansekap di KPHP Meranti, Provinsi Sumatera Selatan," Palembang, 2017.

[31] J. Posman Napitu, A. Hidayat, S. Basuni, and S. Sjaf, "Mekanisme Akses Pada Hak Kepemilikan Di Kesatuan Pengelolaan Hutan Produksi Meranti, Sumatera Selatan," J. Penelit. Sos. dan Ekon. Kehutan., vol. 14, no. 2, pp. 101-118, 2017.

[32] UPTD KPH Wil I Meranti, "Data KTH UPTD KPH Wil I Meranti," 2018.

[33] F. K. Kalaba, "Forest Policy and Economics Barriers to policy implementation and implications for Zambia ' s forest ecosystems," For. Policy Econ., vol. 69, pp. 40-44, 2016.

[34] Republik Indonesia, Peraturan Pemerintah Republik Indonesia Nomor 6 Tahun 2007 Tentang Tata Hutan dan Penyusunan Rencana Pengelolaan Hutan, Serta Pemanfaatan Hutan. 2007, pp. 1-88.

[35] A. Kusumandari and P. Nugroho, "Land capability analysis based on hydrology and soil characteristics for watershed rehabilitation," in Procedia Environmental Sciences, 2015, vol. 28, no. The 5th Sustainable Future for Human Security (SustaiN 2014), pp. 142-147.

[36] Republik Indonesia, Peraturan Presiden Republik Indonesia Nomor 88 Tahun 2017 Tentang Penyelesaian Penguasaan Tanah dalam Kawasan Hutan, no. Lembaran Negara Republik Indonesia nomor 196, 2017. 2017.

[37] S. Ekawati and D. R. Nurrochmat, "Hubungan Modal Sosial Dengan Pemanfaatan Dan Kelestarian Hutan Lindung," J. Anal. Kebijak. Kehutan., vol. 11 (1), no. April, pp. 40-53, 2014.

[38] C. Wulandari, P. Budiono, and D. R. Nurrochmat, "Kesiapan Daerah Dalam Implementasikan Program Tentang Pemerintahan Daerah," Risal. Kebijak. Pertan. dan Lingkung., vol. 3 (2), no. Agustus, pp. 108-116, 2016.

[39] E. Wilujeng, "Implementasi Kebijakan Pengelolaan Hutan Bersama Masyarakat (PHBM) dalam Rangka Pelestarian Hutan Di KPH Blora," Kebijak. dan Manaj. Publik, vol. 3, no. April, pp. 1-10, 2015.

[40] I. S. Ruhimat, "Impelementasi Kebijakan Kesatuan Pengelolaan Hutan ( KPH ) di Kabupaten Banjar," J. Anal. Kebijak. Kehutan., vol. 7, no. 3, pp. 169$178,2010$.

[41] E. A. Waluyo, N. A. Ulya, and E. Martin, "Perencanaan sosial dalam rangka pengembangan hutan rakyat di sumatera selatan," J. Penelit. Hutan dan Konserv. Alam, vol. VII (3), pp. 271-280, 2010.

[42] Taufiqurrohman, "Implementasi Kebijakan Kehutanan Masyarakat (Studi Kasus Hutan Kemasyarakatan di Dusun Kalibiru, Kulon Progo)," Universitas Gajah Mada, 2014.

[43] M. A. K. Sahide et al., Kajian Dampak Perhutanan Sosial Provinsi Sulawesi Selatan, no. December. Makassar: Fakultas Kehutanan UNHAS, 2018.

[44] L. O. Ifrisal, H. Kartodihardjo, and B. Nugroho, "Implementasi Kebijakan Hutan Tanaman Rakyat di Kabupaten Muna Sulawesi Tenggara," J. Silvikultur Trop., vol. 07, no. 3, pp. 159-164, 2016. 